\title{
Torch Infection and its Management with Ayurveda, an Indigenous Medicine
}

\author{
Sukumar N, Namrata B* , Skandan KP, Anita D and Swarda U
}

Department of Kayachikitsa (Rasayana-Vajeekarana), Shri BMK Ayurveda Mahavidyalaya, KLE Academy of Higher Education and Research Centre, India

*Corresponding author: Namrata B, Department of Kayachikitsa (Rasayana-Vajeekarana), Shri BMK Ayurveda Mahavidyalaya, KLE Academy of Higher Education and Research Centre, Belagavi 590003, India, Tel: 0831244 4444; E-mail: bnamratabhagaje@gmail.com

Rec date: January 21, 2018; Acc date: February 05, 2018; Pub date: February 09, 2018

Citation: Sukumar N, Namrata B, Skandan KP, Anita D, Swarda U (2018) Torch Infection and its Management with Ayurveda, an Indigenous Medicine. Gynecol Obstet Case Rep Vol.4:No.1:59.

\section{Abstract}

Abortion is a personal and emotional loss to young couple planning to start a family. Full term delivery is necessary for healthy progeny. Recurrent pregnancy loss is a common presentation reported in childbearing age. Multifactor are responsible for pregnancy loss. TORCH (Toxoplasmosis, Rubella, Cytomegalo virus, Herpes simplex) infection is one among them. We present here a case of a 32-year-old woman who approached outpatient department of Srishti fertility centre of Shri BMK Ayurvedic Hospital with complaint of no issues after 7 years of married life. Her history revealed she suffered from TORCH infection and had three abortions. She sought care at different fertility centres and underwent IUI twice, with no positive result. She was treated with Ayurvedic medication as mentioned in classical textbooks (1500 BC), she conceived and delivered a full term healthy baby without any complication.

Keywords: TORCH; Repeated abortion; Habitual abortion; Ayurveda; Pregnancy loss

\section{Introduction}

Ayurveda is a well-established ancient system of medicine known to mankind. According to Ayurveda four pillars for conception are fertile period, healthy endometrium or implanting bed or uterus, proper nourishment, healthy ovum and sperms [1]. Any derangement in these factors leads to fetal abnormalities, causing Infertility [1]. Presently pregnancy loss is the common presentation causing distress to couples as well as physicians. Great Ayurvedic forefathers had illustrated this under multiple concepts. Uterine abnormality is one among them [1]. According to Ayurvedic classics repeated abortion (Putraghni yonivyapat) is an inflammatory disorder [2], written as "early loss of pregnancy".

It is evident that maternal infections play vital role in loss of pregnancy [3]. Recurrent pregnancy loss is defined as three or more consecutive pregnancy losses at $\leq 20$ weeks of gestational age or with a fetal weight $<500$ grams [4]. It may occur due to genetic abnormality, immune factors, life style, ovarian factors, environmental factors stress and various infections [5]. Prenatal and perinatal infections play important role in manifestation of recurrent pregnancy loss under TORCH acronym (Toxoplasmosis, Rubella, Cytomegalo virus, Herpes simplex) $[6,7]$. Primary infection caused by TORCH is major cause of bad obstetric history [8]. Mainly if infected with Rubella and Cytomegalo virus pregnancy is lost through spontaneous abortions [3]. This is detailed in Ayurvedic texts.

\section{Case Report}

We present here a case study of a woman with TORCH infection which was successfully managed with Ayurvedic treatment. A 32-year-old female professional software engineer visited outpatient department of Shristi fertility centre at B.M. Kankanwadi Ayurvedic Hospital KLE University with complaint of no issues, marital life of 7 years with trying period of 5 years with regular intercourse and slight dyspareunia and proper sexual knowledge. She had a history of regular menses 4-5/28-30 days with no clots or dysmenorrhea. Her past history showed no any other comorbid illness like HTN/DM. Thyroid profile was within normal limit. She had a history of 2 abortion consecutively and 1 termination because of absence of cardiac activity and presence of empty fetal sac in last three years. Family history showed all family members were healthy. Her previous treatment details showed coarse of antibiotic therapy and twice IUI with no positive outcome. Clinical examination showed her as normal.

\section{Investigations}

Previous USG scan reported pregnancy loss and termination due to absence of fetal cardiac activity and empty fetal sac. HSG revealed presence of Right fimbrial block. Thyroid profile, Complete blood count and Karyotyping was Normal. TORCH panel revealed IgG Toxoplasmas: 6.50; IgG Cytomegalovirus: 239.80; IgG to Rubella: 105.50. Partner profile was normal.

\section{Discussion}

On the above findings and investigations case was diagnosed to be as recurrent pregnancy loss due to TORCH. 
This infection can be fatal by harming fetal development leading to repeated pregnancy loss by utero infection, which has to be treated accordingly $[2,10]$. During intrauterine period ability of fetus to resist organisms is limited and fetal immune system is unable to prevent the dissemination of infectious organisms [11].

Purgation is the best treatment in inflammatory disorders [9]. Ayurvedic treatment was started with seven days authentic purgation therapy with processed castor oil under strict monitoring for detoxification of antibodies and neuro endocrinal proper functioning. This is followed by herbal oral medication* for a month aimed to achieve proper ovulation, implantation, microcirculation, fetal development, immune modulation and prevention of abortion. Along with this local vaginal tampon insertion with medicated oil for 7 days was done to relieve local infection and dyspareunia. Patient conceived and regular antenatal care check-up with regular USG showed wellbeing of both growing fetus and mother. She delivered a healthy full term normal male baby weighing $2600 \mathrm{gm}$ with no post-delivery complications.

\section{Conclusion}

As a conclusion recurrent abortion due to TORCH infection in this woman was managed with Ayurvedic treatment such as detoxification, herbal decoctions, tablets AND local procedures*. In present case, patient became pregnant and delivered full-term healthy baby.

*Details of the oral medications and procedures will be provided on request.

\section{References}

1. Tivari P (2009) Ayurvediya Prasuti Tantra Evam Stree Roga II. Varanasi, Chaukhambha orientalia 42-44: 273,276.
2. Tripati R (2012) Charakasamhitall. Delhi, Chaukhamba Sanskrita Pratishthan. p. 337.

3. Sadik MS, Fatima H, Patil C (2012) Study of TORCH profile with bad obstetric history. Biol Med 4: 95-101.

4. Cunningham GF, Leveno KJ, Bloom LS, HC John C, Hanth, et al. Grawhill Medical, William obstetrics, Chapter 9 Abortion (23rd edn). Catherine Y. Spong MD, MC. p. 224.

5. Dutta DC (2005) Textbook of Obstetrics. Kolkata, New central book Agency(P), Itd. (7th edn). pp.159-160.

6. Nickerson JP, Richer B, Santy K, Lequin MH, Poretti A, et al. (2012) Neuroimaging of pediatric intracranial infection, Part 2: TORCH, viral, fungal and parasitic infections. J Neuroimaging 22: 42-51.

7. Maldonado YA, Nizet V, Klein JO, Remington JS, Wilson CB (2010) Current concepts of infections of the fetus and newborn infant. In Infectious Diseases of the Fetus and Newborn Infant. (7th edn); Remington JS, Klein JO, Wilson CB, Nizet V, Maldonado YA (eds) Philadelphia, PA Elsevier Saunders, USA. p. 1-23.

8. McCabe R, Remington JS (1988) Toxoplasmosis, the time has come. New Engl J Med 318: 313-315.

9. Binnicker MJ, Jespersen DJ, Harring JA (2010) Multiplex detection of IgM and IgG class antibodies to Toxoplasma gondii, Rubella virus, and cytomegalovirus using a novel multiplex flow immunoassay. Clin Vaccine Immunol 17: 1734-1738.

10. Maruyama $\mathrm{Y}$, Sameshima $\mathrm{H}$, Kamitomo M, Ibara S, Kaneko M, et al. (2007) Fetal manifestations and poor outcomes of congenital cytomegalovirus infections: possible candidates for intrauterine antiviral treatments. J Obstet Gynaecol 33: 619-623.

11. Mladina N, Mehikic G, Pasic A (2000) Torch infections in mothers as a cause of neonatal morbidity. Med Arch 54: 273-276. 